\title{
Histochemical evaluation of sodium aurothiomalate inhibition of mouse sperm enzymes*
}

\author{
R. Waibel†, G. M. Oldford, G. Ficsor and L. C. Ginsberg \\ Department of Biomedical Sciences, Western Michigan University, Kalamazoo, Michigan 49008, \\ U.S.A.
}

\begin{abstract}
Summary. Histochemical procedures for the mouse sperm enzymes hyaluronidase, esterase and acrosin were used to test the inhibitory effects of the low molecular weight hyaluronidase inhibitor sodium aurothiomalate (Myocrisin): hyaluronidase and esterase, but not acrosin, were inhibited. These enzymes were also inhibited in testis homogenates when assayed spectrophotometrically. These results suggest that the antifertility effects of sodium aurothiomalate may be due to the inhibition of several sperm enzymes including both hyaluronidase and esterase. These histochemical assays may be useful for in-vivo detection of chemicals that affect male fertility.
\end{abstract}

\section{Introduction}

Three major acrosomal enzymes, hyaluronidase (McRorie \& Williams, 1974), the corona penetrating enzyme (CPE) (Zaneveld \& Williams, 1970), now believed to be an esterase (Bradford, McRorie \& Williams, 1976a, b), and acrosin (McRorie \& Williams, 1974), may have a role in fertilization. Each of these enzymes may be required for the passage of the spermatozoon through the various layers of the ovum. Inhibitors of these enzymes should therefore prevent fertilization (Zaneveld, 1976) and may have potential as contraceptives. In the 1950s, a number of synthetic hyaluronidase inhibitors were tested to determine their effects on fertilization. The results obtained were inconclusive. One of the major problems with these inhibitors may have been their relatively high molecular weight which prevented them from reaching the enzymes they were to inhibit. However, a decrease in the in-vitro fertilization rate has been reported in the hamster and the mouse after treatment with the low molecular weight inhibitor sodium aurothiomalate (Reddy, Joyce \& Zaneveld, 1980; Perreault, Zeneveld \& Rogers, 1980). Sodium aurothiomalate has also been shown to inhibit hyaluronidase in vitro (Caygill \& Ali, 1969). The advantage of this inhibitor as an antifertility compound is that it shows only moderate toxicity and it is approved by the FDA for treatment of arthritis.

The aim of this study was to determine whether the antifertility effect of this compound is due to the inhibition of hyaluronidase only or also to inhibition of other sperm enzymes such as acrosin and esterases.

\section{Materials and Methods}

\section{Histochemical assay}

Sperm preparation. Mouse spermatozoa were extracted from the vasa deferentia and suspended in $1 \mathrm{ml}$ sperm Ringer solution (Ficsor, Ginsberg, Oldford, Snoke \& Becker, 1983). Spermatozoa

* Reprint requests to: Dr L. C. Ginsberg.

† Present address: Department of Obstetrics and Gynecology, Duke University Medical Center, Durham, NC 27710, U.S.A. 
were washed twice with 10 volumes of sperm Ringer. After each washing the sperm suspension was collected by centrifugation at $600 \mathrm{~g}$ for $3 \mathrm{~min}$. The sperm pellet was resuspended in $0.1 \mathrm{ml}$ sperm Ringer containing $0,2 \cdot 5,5$ or $10 \mathrm{mg}$ sodium aurothiomalate/ml (Myocrisin: Aldrich, Milwaukee, WI, U.S.A.) or 3 or $5 \mathrm{mg}$ TLCK ( $N$-a-p-tosyl-1-lysine chloromethyl ketone/ml: Sigma, St Louis, MO, U.S.A.) and was incubated at $37^{\circ} \mathrm{C}$ for $20 \mathrm{~min}$. The sperm suspension $(10 \mu \mathrm{l})$ was spread onto a substrate film (acrosin or hyaluronidase) or a clean glass slide (esterase). Two hundred spermatozoa per slide were scored from 5 mice for each of the doses of inhibitor used.

Hyaluronidase substrate film assay. The hyaluronic acid agarose-coated GelBond sheets were cut into $20 \times 50 \mathrm{~mm}$ rectangles and were mounted on microscope slides (Waibel, Ginsberg \& Ficsor, 1984): $10 \mu \mathrm{l}$ mouse sperm suspension with or without inhibitor were spread onto each substrate-film slide and incubated in a humidity chamber (wet box) for $3 \mathrm{~h}$ at $37^{\circ} \mathrm{C}$. After incubation, the slides were fixed for $15 \mathrm{~min}$ in formaldehyde-acetone $(20 \mathrm{ml}$ of $37 \%$ formaldehyde mixed with $80 \mathrm{ml}$ acetone), and stained in a solution of $0.3 \%$ toluidine blue and $0.2 \%$ fast green FCF in $80 \%$ acetonewater containing $0.5 \%$ acetic acid. The films were destained in a solution of $2 \%$ acetic acid in $80 \%$ acetone-water. The fixed and stained slides were scored for hyaluronidase activity which occurred as dark purple halos around the sperm head.

Acrosin substrate film assay. Spermatozoa were placed on gelatin-substrate films (Ficsor $e$ t al., 1983) and incubated in a wet box for $30 \mathrm{~min}$ at $37^{\circ} \mathrm{C}$. After incubation, the slides were dipped in distilled water, stained in $0.3 \%$ toluidine blue in $0.1 \mathrm{M}$-borate buffer at $\mathrm{pH} 10$, destained in distilled water and dried. The stained slides were scored for acrosin activity which appears as protein-free clear halos around the sperm head.

Esterase activity assay. The histochemical procedure for the detection of esterase activity was modified from the staining procedure of Bryan \& Unnithan (1973) for esterase activities in mice: $0.5 \mathrm{ml} 4 \%$ sodium nitrite was mixed with $0.5 \mathrm{ml} 4 \%$ pararosanilidine $\mathrm{HCl}$ in $2 \mathrm{~N}-\mathrm{HCl}$ and allowed to activate for $20 \mathrm{~min}$ at room temperature before being added to $10 \mathrm{ml} 0.1 \mathrm{M}$-acetate buffer $\mathrm{pH} 5.0$ with $5 \mu \mathrm{M}$-calcium chloride. The $\mathrm{pH}$ of this reaction mixture was readjusted to $\mathrm{pH} 5.0$ with $1 \mathrm{M}$ $\mathrm{NaOH}$ and $1 \mathrm{ml}$ of this hexazonium reagent was mixed with $50 \mu \mathrm{l} 1 \%$ naphthyl caproate dissolved in acetone. The mixture was allowed to stand for $30 \mathrm{~min}$ at room temperature before filtering. The enzyme reaction was started by spreading $100 \mu \mathrm{l}$ sperm suspension on a microscope slide. After partial drying the slides were transferred to a wet box and flooded with $1 \mathrm{ml}$ of the prepared incubation medium. After incubation for $2 \mathrm{~h}$ at $37^{\circ} \mathrm{C}$ the slides were rinsed in distilled water and mounted with $20 \%$ Elvanol (DuPont, Wilmington, DE, U.S.A.). Spermatozoa with esterase activity exhibited red colouring in the dorsal area of the head.

\section{Spectrophotometric enzyme assays}

Enzyme activity was determined spectrophotometrically on crude Triton X-100 extracts of mouse testis and on $0.1 \%$ bovine hyaluronidase type 1 (Sigma, St Louis, MO, U.S.A.) in the appropriate buffer.

Testicular extract. Testes were homogenized in acetate buffer $(\mathrm{pH} 5 \cdot 0,0 \cdot 1 \mathrm{M})$ containing $1 \%$ Triton X-100. The suspension was sonicated and centrifuged at $45000 \mathrm{~g}$ for $1 \mathrm{~h}$. The supernatant was used as a source of crude mouse testis enzymes.

Hyaluronidase assay. Hyaluronidase was measured by a micromethod (Doak \& Zahler, 1979): $50 \mu \mathrm{l}$ of a $1 \%$ hyaluronic acid solution (sodium or potassium salt) in $0.05 \mathrm{M}$-acetate buffer $\mathrm{pH} 3.8$ and $0.15 \mathrm{M}$-sodium chloride was mixed with $10 \mu 11 \%$ bovine serum albumin solution and increasing inhibitor concentrations (see 'Results'). The reaction was initiated by adding $50 \mu$ l enzyme solution and incubation was for $30 \mathrm{~min}$ at $37^{\circ} \mathrm{C}$. The free $N$-acetylglucosamine endgroups produced by hyaluronidase were estimated as described by Reissig, Strominger \& Leloir (1955).

Esterase assay. For measurement of aryl-esterase activity, the substrate 4-caproyloxy-3methoxy- $\omega$-nitrostyrene was synthesized. The caproyl derivative was prepared by heating $4 \mathrm{~g} \mathrm{4-}$ hydroxy-3-methoxy- $\omega$-nitrostyrene (Yuen, Price, Richardson \& Praill, 1981), a chromophoric 


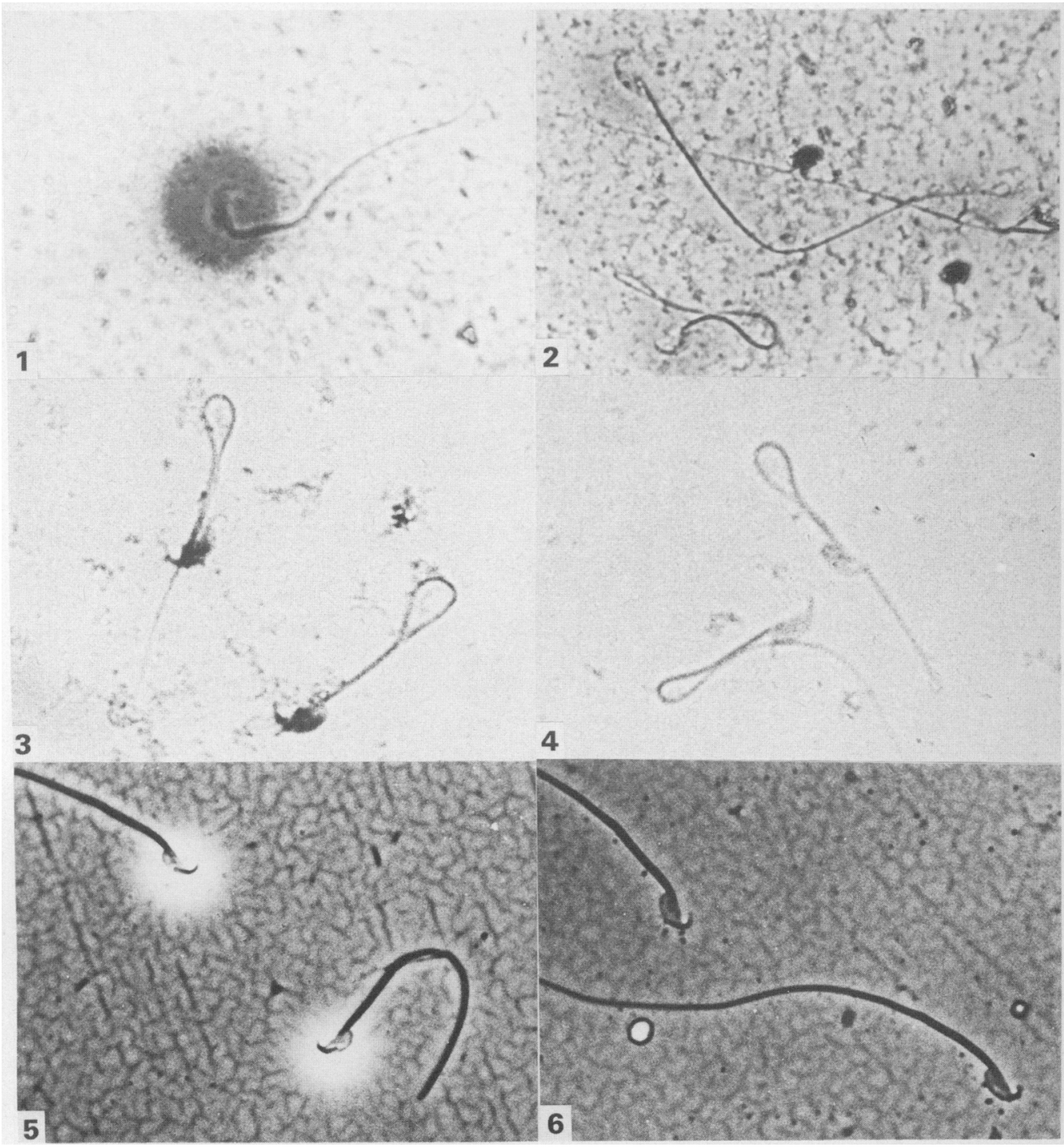

Histochemical analysis of inhibition of mouse sperm enzymes by sodium aurothiomalate and TLCK.

Fig. 1. Hyaluronidase activity, no sodium aurothiomalate.

Fig. 2. Hyaluronidase activity in presence of $10 \mathrm{mg}$ sodium aurothiomalate $/ \mathrm{ml}$.

Fig. 3. Esterase activity, no inhibitor.

Fig. 4. Esterase activity, $10 \mathrm{mg}$ sodium aurothiomalate $/ \mathrm{ml}$.

Fig. 5. Acrosin activity, $10 \mathrm{mg}$ sodium aurothiomalate $/ \mathrm{ml}$ (no inhibition).

Fig. 6. Acrosin activity, $5 \mathrm{mg} / \mathrm{TLCK} / \mathrm{ml}$. 
phenol, in $15 \mathrm{ml}$ anhydrous pyridine together with $3.5 \mathrm{~g}$ caproyl chloride under reflux for $5 \mathrm{~min}$. The hot solution was poured into ice-water and the precipitated yellow product was collected by filtration and recrystallized from chloroform :ethanol $(1: 1, \mathrm{v} / \mathrm{v})$. Esterase activity was measured using a reaction mixture of $0.2 \mathrm{ml}$ of a $0.01 \%$ substrate solution in ethylene glycol added to $0.2 \mathrm{ml} 0.1 \mathrm{M}$ citrate buffer $\mathrm{pH} 5$ containing $5 \mu \mathrm{M}$-calcium chloride. The reaction was initiated by adding $0 \cdot 1 \mathrm{ml}$ enzyme solution. After incubation for $30 \mathrm{~min}$ at $37^{\circ} \mathrm{C}$ the reaction was stopped with $50 \mu$ ice-cold $n$ butanol. Before reading the absorbance at $505 \mathrm{~nm}, 0.5 \mathrm{ml} 0.5 \mathrm{M}-$ Tris- $\mathrm{HCl}$ buffer $\mathrm{pH} 8.5$ was added to develop the red colour of the product.

\section{Results}

\section{Histochemical analysis}

Sodium aurothiomalate inhibited hyaluronidase and esterase activity under the conditions tested, but acrosin activity was not affected (Text-fig. 1a). With increasing inhibitor concentration, the size of the lysis areas on hyaluronic acid films decreased and became indistinct. At $10 \mathrm{mg} / \mathrm{ml}$, lytic activity was absent (Pl. 1, Figs $1 \& 2$ ). Inhibition of esterase activity was shown by a decrease of the frequency of spermatozoa with red hexazonium substrate complex precipitation in the sperm head (Pl. 1, Figs 3 \& 4).

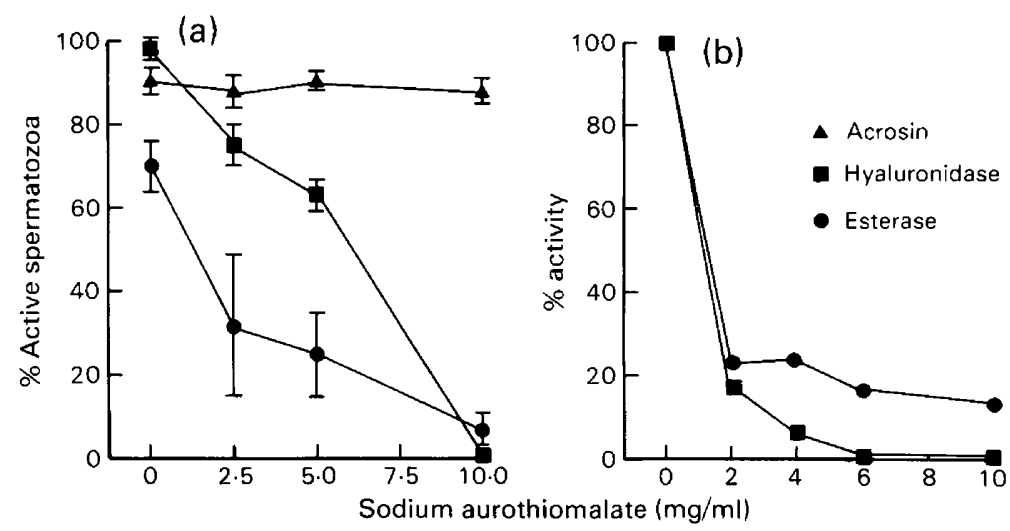

Text-fig. 1. Inhibition by sodium aurothiomalate of the mouse sperm enzymes (a) in individual spermatozoa by histochemical methods and (b) in homogenates of mouse testis determined spectrophotometrically. Values are mean \pm s.e.m. for 5 mice.

Even at the concentration of $10 \mathrm{mg}$ inhibitor $/ \mathrm{ml}$, acrosin activity was not inhibited. In contrast, the protease inhibitor TLCK $(3 \mathrm{mg} / \mathrm{ml})$ decreased the activity to small fuzzy digestion areas on the substrate films. At the concentration of $5 \mathrm{mg} \mathrm{TLCK} / \mathrm{ml}$ the acrosin activity was completely inhibited (PI. 1, Figs $5 \& 6$ ). TLCK in these concentrations did not show any effect on hyaluronidase or esterase activity.

\section{Spectrophotometric analysis}

Because acrosin is known to be inactive in mouse testis, the inhibition experiment with crude mouse testis was limited to the study of hyaluronidase and esterase. As expected, both hyaluronidase and esterase were inhibited by increasing concentrations of sodium aurothiomalate (Text-fig. 1b). This confirmed a similar observation with commercially available bovine hyaluronidase (data not shown). 


\section{Discussion}

Reddy et al. (1980) showed that sodium aurothiomalate blocked fertilization of the mouse ovum in vitro and they suggested that the antifertility effect was caused by inhibition of hyaluronidase, an enzyme thought to disperse the cumulus cells by breaking down hyaluronic acid. However, Perreault et al. (1980) found that sodium aurothiomalate inhibits fertilization of cumulus-free hamster eggs. These results suggest that (i) hyaluronidase has an additional unknown function in fertilization and/or (ii) that other enzymes necessary for fertilization may be inhibited.

Our results confirm that sodium aurothiomalate inhibits hyaluronidase activity in single mouse spermatozoa and in testicular cells (Caygill \& Ali, 1969; Ghosh, Stephens \& Taylor, 1975). When mouse spermatozoa were assayed microchemically for esterase activity there was decreased activity in the samples treated with sodium aurothiomalate. Similar results were obtained with the spectrophotometric methods for measuring esterase activities in testis homogenates. Our results support the hypothesis that sodium aurothiomalate inhibits fertilization by inhibiting hyaluronidase and esterase. These results also suggest that esterase may be involved in the fertilization process at a step after the dispersal of the cumulus. However, we cannot rule out inhibition of other sperm enzymes. Acrosin, an enzyme needed for penetration of the zona pellucida, was not inhibited by sodium aurothiomalate in the histochemical gel film assay. The ability to detect the inhibition of acrosin in our histochemical sperm system was verified by the TLCK inhibition experiment, which showed inhibition in a dose-dependent manner.

The substrate synthesized for the colorimetric measurement of the caproyl-esterase activity is new: it is more stable than the nitrophenyl esters (Aldrige, 1953) and does not require a coupling reagent to achieve visualization (Kass, 1979). We also noted that calcium ions were important in the measurement of this esterase, particularly at low enzyme concentration.

The improved histochemical assays for hyaluronidase and acrosin in single spermatozoa that we developed earlier and the esterase assay reported here could be useful for the detection in vivo of chemicals which cause loss of these enzyme functions. Since these enzymes are necessary for fertilization, the detection of the loss of these enzyme functions may be useful for identifying chemicals with antifertility effects.

We thank Dr B. B. Panda for assistance with photography. This work was supported by grant 5 R01 ES02607-02 from the National Institute of Environmental Health Science.

\section{References}

Aldrige, W.N. (1953) Serum esterase. 1. Two types of esterase (A and B) hydrolysing p-nitrophenylacetate, propionate and butyrate and a method for their determination. Biochem. $J$. 53, 110-117.

Bradford, M.M., McRorie, R.A. \& Williams, W.L. (1976a) A role of esterases in the fertilization process. J. exp. Zool. 197, 297-301.

Bradford, M.M., McRorie, R.A. \& Williams, W.L. (1976b) Involvement of esterases in sperm penetration of the corona radiata of the ovum. Biol. Reprod. $15,102-106$

Bryan, J.H.D. \& Unnithan, R.R. (1973) Cytochemical localization of non specific esterase and acidic phosphatase in spermatozoa of the mouse (Mus musculus). Histochemie 33, 169-180.

Caygill, J.C. \& Ali, Z. (1969) Degradation of synovial fluid and hyaluronic acid by serum and testicular hyaluronidase and by L-ascorbic acid and the effect of inhibitors. Clin. Chim. Acta 26, 395-400.
Doak, G.A. \& Zahler, W.L. (1979) Stimulation of bull sperm hyaluronidase by polycations. Biochem. Biophys. Acta 570, 303-310.

Ficsor, G., Ginsberg, L.C., Oldford, G.M., Snoke, R.E. \& Becker, R.W. (1983) Gelatin-substrate film technique for detection of acrosin in single mammalian sperm. Fert. Steril. 39, 548-552.

Ghosh, P., Stephens, R.W. \& Taylor, T.K.F. (1975) The inhibition of synovial fluid polysaccharides by gold sodium thiomalate. Med. J. Aust. 1, 317.

Kass, L. (1979) Cytochemistry of esterases. CRC Clin. Lab. Sci. 10, 205-223.

McRorie, R.A. \& Williams, W.L. (1974) Biochemistry of mammalian fertilization. A. Rev. Biochem. 43, 777803.

Perreault, S., Zaneveld, L.J.D. \& Rogers, B.J. (1980) Inhibition of fertilization in the hamster by sodium aurothiomalate, a hyaluronidase inhibitor. J. Reprod. Fert. 60, 461-467. 
Reddy, J.M., Joyce, C. \& Zaneveld, L.J.D. (1980) Role of hyaluronidase in fertilization: the antifertility activity of Myocrisin, a nontoxic hyaluronidase inhibitor. J. Androl. 1, 28-32.

Reissig, J.L., Strominger, J.L. \& Leloir, L.F. (1955) A modified colorimetric method for the estimation of $N$-acetylamino sugars. J. biol. Chem. 217, 959-966.

Waibel, R., Ginsberg, L.C. \& Ficsor, G. (1984) Cytochemical detection of hyaluronidase activity in single human and mouse sperm by an improved substratefilm technique. Histochem. Cytochem. 32 (in press).

Yuen, C.Y., Price, R.G., Richardson, A.C. \& Praill, P.F.G. (1981) The assay of arylesterase in serum using two new colorimetric substrates, $\omega$-nitrostyrylacetate and propionate. Clin. Chim. Acta 112, 99-105.

Zaneveld, L.J.D. (19i6) Sperm enzyme inhibitors as antifertility agents. In Human Semen and Fertility Regulation in Men, pp. 570-582. Ed. E. S. E. Hafez. C.V. Mosby Company, St. Louis.

Zaneveld, L.J.D. \& Williams, W.L. (1970) A sperm enzyme that disperses the corona radiata and its inhibition by decapacitation factor. Biol. Reprod. 2, 363-368.

Received 4 May 1983 